Article

\title{
Effects of Tillage and Crop Residue Application on Soybean Nitrogen Fixation in a Tropical Ferralsol
}

Job Kihara ${ }^{1,2, *}$, Christopher Martius ${ }^{2}$, Andre Bationo ${ }^{3}$ and Paul L. G. Vlek ${ }^{2}$

1 Tropical Soil Biology and Fertility (TSBF) Institute of CIAT, Box 30677, Nairobi 00100, Kenya

2 Zentrum für Entwicklungsforschung (ZEF), Walter-Flex Str. 3, Bonn 53113, Germany; E-Mails: c.martius@uni-bonn.de (C.M.); p.vlek@uni-bonn.de (P.L.G.V.)

3 Alliance for Green Revolution in Africa (AGRA-Alliance), CSIR Office Complex, \#6 Agostino Neto Road, Airport Residential Area, PMP KIA 114, Airport-Accra, Ghana; E-Mail: abationo@agra-alliance.org

* Author to whom correspondence should be addressed; E-Mail: mjob@daad-alumni.de; Tel.: +254-722626219.

Received: 25 October 2011; in revised form: 6 December 2011 / Accepted: 8 December 2011 / Published: 20 December 2011

\begin{abstract}
This study was aimed at quantifying soybean (Glycine max) nitrogen fixation under reduced tillage (RT) and conventional tillage (CT) in a tropical Ferralsol of the sub-humid zone of western Kenya, using the isotope ${ }^{15} \mathrm{~N}$ dilution method. Crop residue (CR) management was a superimposed treatment in soybean-maize rotation and intercropping systems. This study quantified $\mathrm{N}$ in abscised soybean leaves. Soybean-N derived from the atmosphere (\%NDfA) ranged between 41-65\%; it was higher $(P<0.05)$ in RT (55.6\%) than in CT (46.6\%). Total fixed-N under 'RT + CR' was more than in the other treatments by at least 55\% in intercropping and $34 \%$ in rotation system. Nitrogen fixed in soybean aboveground parts was $26-48 \mathrm{~kg} \mathrm{~N}^{-1}$ with intercropping and 53-82 $\mathrm{kg} \mathrm{N} \mathrm{ha}^{-1}$ with rotation. Seasonal litter fall contained about $15 \mathrm{~kg} \mathrm{~N}^{-1}$, with $54 \%$ NDfA. Annual nitrogen balances with soybean and maize grain removed were better in RT ( -9 to $\left.-32 \mathrm{~kg} \mathrm{~N}^{-1}\right)$ than in $\mathrm{CT}\left(-40\right.$ to $\left.-60 \mathrm{~kg} \mathrm{~N}^{-1}\right)$. Application of $\mathrm{P}$ increased nodule weight $(P<0.05)$ by 3 to 16 times over the control. Soybean residues should be returned to the field after harvest to reduce soil $\mathrm{N}$ mining. We conclude that ' $\mathrm{RT}+\mathrm{CR}$ ' increases biological nitrogen fixation in soybean, over $\mathrm{CT}$, and that phosphorus application is needed for better soybean nodulation in western Kenya.
\end{abstract}


Keywords: intercropping; litter fall; $\mathrm{N}$ balance; $\% \mathrm{NDFA} ;{ }^{15} \mathrm{~N}$ dilution

\section{Introduction}

Relying on the biological nitrogen fixation (BNF) of grain legumes is a strategy to ease the burden that commercial fertilizers exert on poor farmers. In sub-Saharan Africa (SSA), fertilizer use is estimated at $8 \mathrm{~kg} \mathrm{ha}^{-1}$, which is only 10\% of the worlds' average [1]. Stoorvogel et al. (1993) pointed out gross annual nitrogen mining in SSA averaging $22 \mathrm{~kg} \mathrm{~N} \mathrm{ha}^{-1}$, but up to $100 \mathrm{~kg} \mathrm{~N} \mathrm{ha}^{-1}$ in some cases [2]. The unique socio-economic conditions and wide-spread rural poverty in sub-Saharan Africa limit access to mineral fertilizers, inducing the search for cheap sources of fertilization, such as nitrogen fixation by grain legumes. Soybean has been produced in Kenya for several years on a small scale, but demand for proteins and biodiesel has renewed interest in its production. Promiscuous soybean varieties (varieties that do not require inoculation with specific Rhizobium) have recently been introduced to western Kenya for soil fertility improvement, through the Tropical Soil Biology and Fertility institute of CIAT (TSBF-CIAT), and their performance is being tested in various agro-ecological zones.

The amount of nitrogen fixed by grain legumes such as soybean is affected by the degree of colonization by soil rhizobia [3], by their interaction with other biological, physical and chemical properties of the soil [4-6] and by weather [7]. These factors, except weather, are themselves influenced by management practices such as tillage and crop residue (CR) application as well as by the spatial-temporal arrangement of crop components. Reduced soil disturbance, for example, improves soil physical parameters such as structure, but also the chemical and biological parameters that affect nitrogen fixation. Soil moisture and temperature, for example, which are influenced by tillage and CR, affect biological nitrogen fixation [8]. Legumes such as soybean that transport $\mathrm{N}$ fixed from roots to shoots in the form of ureides (allantoin and allantoic acid) are particularly susceptible to water stress [9], and conservation practices involving reduced tillage and surface $\mathrm{CR}$ application are expected to positively influence nitrogen fixation. Also, CR management affects decomposition of the residue and rates of N-release to the soil pool, thus affecting nitrogen fixation $[5,10]$. Small-scale crop production in eastern Africa takes place mostly without mulching, but about $2 \mathrm{tha}^{-1}$ of low-quality CR can be applied or just remain from the previous cereal crop. It is not known to which extent such low-quality CR mulch, in quantities available and affordable by small-scale farmers, affects proportion and total amount of nitrogen fixed by soybean in eastern Africa. The effect of CR on nitrogen fixation in grain legumes has been investigated on sandy soils [6], but no work on tropical African Ferralsols could be found.

Within smallholder production systems, soybean is produced in rotation or intercropping with cereals. Quantifying the contribution of soybean to the nitrogen balance in these systems under different tillage and residue management scenarios is important for optimization of BNF. Appreciable amounts of soybean leaves can be shed during the soybean crop cycle thus contributing to the N-balance in these systems. Peoples and Craswell (1992) noted that frequently, only standing shoot 
data and no leaf-fall data are available, and therefore net N-balances are underestimated in many studies [10].

This study aimed to quantify nitrogen fixation of soybean under reduced and conventional tillage with different CR management in a sub-humid zone of western Kenya. We hypothesized that practicing reduced tillage combined with $\mathrm{CR}$ application leads to a greater proportion of nitrogen derived from the atmosphere (\%NDfA) and to greater total nitrogen fixed, compared to reduced tillage without CR application, and also compared to conventional tillage systems.

\section{Materials and Methods}

\subsection{Site and Soil Type}

The study was conducted in a soybean-maize rotation and intercropping system on a tropical Ferralsol during the long rains in 2007 in Nyabeda, western Kenya. The soils are characterized by 64\% clay, $15 \%$ sand, $\mathrm{pH}$ water $5.1,1.35 \%$ total $\mathrm{C}, 0.15 \%$ total $\mathrm{N}$ and $2.99 \mathrm{mg}$ available $\mathrm{P} \mathrm{kg}^{-1}$ soil. The site, at $0^{\circ} 07^{\prime} \mathrm{N} 34^{\circ} 24^{\prime} \mathrm{E}$ and $1420 \mathrm{~m}$.a.s.l receives an annual rainfall of $1200-1600 \mathrm{~mm}$ which is distributed in two distinct seasons: long rains season from March to August and short rains season from September to February. The experiment was established as a long-term conservation tillage trial in March 2003 and was set up with a factorial design involving tillage (reduced tillage [RT] and conventional tillage [CT]), CR application (maize stover applied at 0 and $2 \mathrm{t} \mathrm{ha}^{-1}$ ) and cropping systems (legume-cereal intercropping and rotation). Under RT, tillage was restricted to surface-scratching down to $3 \mathrm{~cm}$ depth to remove weeds, while CT involved tillage with hand hoes to about $10-15 \mathrm{~cm}$ depth as done by small-scale farmers. The legume crop was soybean (Glycine max (L.) Merr) (TGX 1448-2E, locally known as SB20), except in the first season when common bean (Phaseolus vulgaris) was used. Maize (Zea mays L.) was the cereal crop. Legume residues were left on the respective plots after harvest. Nitrogen in form of urea was applied at 0 and $60 \mathrm{~kg} \mathrm{~N} \mathrm{ha}^{-1}$ (split applied with one third at planting and two thirds when crop was at knee height), and $\mathrm{P}$ was applied at 0 and $60 \mathrm{~kg} \mathrm{P}^{-1}$ as triple super phosphate (TSP). All the treatments received a basal application of $60 \mathrm{~kg} \mathrm{~K} \mathrm{ha}^{-1}$ as muriate of potash.

Maize was planted at $0.25 \mathrm{~m}$ (between plants) by $0.75 \mathrm{~m}$ (between rows) with two seeds per planting hole and thinned to one plant per hill $\left(53,000\right.$ hills ha $\left.^{-1}\right)$. Soybean was planted at $0.05 \mathrm{~m}$ (between plants) by $0.75 \mathrm{~m}$ (between rows; 266,000 seeds $\mathrm{ha}^{-1}$ ) in both rotation and intercropping systems, i.e., the legume in the intercrop was superimposed on maize.

\subsection{Soybean Nodulation and Biomass Assessment}

Soybean nodulation was investigated at peak biomass in four different cropping seasons between September 2003 and August 2005. One quadrant measuring $0.75 \mathrm{~m}$ by $0.75 \mathrm{~m}$ was placed on each diagonal of the plot, aboveground shoots cut and roots carefully excavated to $0.2 \mathrm{~m}$ depth, and nodules sorted out by hand. After washing to soil-free, nodules were counted, fresh weights determined, and dry weights determined after oven-drying at $60^{\circ} \mathrm{C}$ for $48 \mathrm{~h}$. 


\subsection{Soybean In-Season Leaf Fall}

Six plastic nets (traps), each measuring $50 \mathrm{~cm}$ by $75 \mathrm{~cm}$, were laid $5 \mathrm{~cm}$ above the soil surface at 6 weeks after planting to collect soybean litter-fall. The leaves and flowers falling in the litter traps were collected weekly starting 61 days after planting and twice weekly from 83 days after planting. Weight of the collected leaves and flowers was taken before and after drying at $60{ }^{\circ} \mathrm{C}$ for 48 hours. At the end of the season, soil-free leaves and flowers for each treatment were bulked by replicate and analyzed for $\mathrm{N}$ content. Soybean leaf and flower debris mixed with soil were also taken, and a subsample ashed at $550{ }^{\circ} \mathrm{C}$ for 5 hours to determine the mineral content (i.e., non-organic component) that was used to estimate leaf and flower biomass in the biomass-soil mixture.

\subsection{Microplots and ${ }^{15} N$ Dilution}

Microplots measuring $2 \times 3 \mathrm{~m}$ and $3 \times 3 \mathrm{~m}$ were established in April 2007 within soybean-maize rotation and intercropping systems, respectively. Urea $\left(-\mathrm{CO}\left({ }^{15} \mathrm{NH}_{2}\right)_{2}\right)$, with atom $\%{ }^{15} \mathrm{~N}$ of $5.30+/-0.05$, was applied at $6 \mathrm{~g}$ and $9 \mathrm{~g}$ in soybean-maize rotation and intercropping systems plots, respectively, split applied $1 / 2$ at planting and $1 / 2$ at 50 days after planting. The target application rate was $4.6 \mathrm{~kg} \mathrm{~N} \mathrm{ha}^{-1}$. The fertilizer was applied in solution to ensure uniform distribution in the soil. Although there is a likelihood that ${ }^{15} \mathrm{~N}$ was not completely equilibrated in the soil in this study, for instance due to application after crop residue application (see [11,12] for best ${ }^{15} \mathrm{~N}$ application practices), it nevertheless provides useful insights into treatment effects. The microplots were planted with nitrogen fixing (F) soybean and non-nitrogen fixing reference (NF) maize plants (maize was used in the absence of a suitable non-fixing soybean cultivar growing in the study area). Limitations of using maize as a reference crop in $\mathrm{N}$-fixation studies, such as seasonal changes in $\% \mathrm{NdFA}$ and indication of lower \%NdFA contribution relative to crops such as rice is discussed by [13]. No inoculation was done, and soybean was expected to self-inoculate with native soil bacteria. Harvesting of the microplots was done at 115 days after planting (at physiological maturity) when the soybean pods turned yellow-to-brown. For aboveground biomass, four maize plants were sampled from each reference plot and their stems, pods and root biomass taken. For soybean, sampling was done for all plants within a distance of $50 \mathrm{~cm}$ from the two ends of the microplot (area of $2 \mathrm{~m}^{2}$ for rotation and $4 \mathrm{~m}^{2}$ for intercropping). Fresh weights for all samples were taken in the field. All aboveground biomass was oven-dried at $60{ }^{\circ} \mathrm{C}$ for 48 hours before taking dry weights.

Root biomass in microplots was assessed in two quadrats of $0.50 \mathrm{~m}$ by $0.75 \mathrm{~m}$ instead of the whole microplot to avoid disturbance in the RT plots. The area was dug out to $15 \mathrm{~cm}$ depth using a hand-hoe and the roots sorted out by hand. Root fresh weights for all root samples were taken in the laboratory after washing to soil-free with de-ionized water, over a $0.5 \mathrm{~mm}$ sieve. The samples were put in the oven immediately after washing and dried at $60{ }^{\circ} \mathrm{C}$ for 48 hours.

Laboratory analysis for total $\mathrm{N}$ and atom $\%{ }^{15} \mathrm{~N}$ was done for each of the plant parts (stems and leaves, pods, grains, and roots) at the Institute of Plant Nutrition Laboratory in Bonn, Germany, using an isotope ratio mass spectrometer ANCA-SL (PDZ Europa, Cheshire, UK, 1998). Soils sampled from soybean-maize rotation, soybean-maize intercropping and continuous maize at the beginning of season 9 (in March 2007) were also analyzed for $\delta^{15} \mathrm{~N}$ concentration. Litter $\mathrm{N}$ was analyzed by wet oxidation 
based on Kjeldahl digestion with sulfuric acid [14] in the ICRAF laboratories in Nairobi, Kenya, and its ${ }^{15} \mathrm{~N} /{ }^{14} \mathrm{~N}$ ratio was assumed to be similar to that of stems plus leaves at physiological maturity.

Calculations to quantify $\mathrm{N}$ fixation followed standard methods [11,15]. Nitrogen balances were calculated by subtracting total $\mathrm{N}$ contained in soybean and maize grain from total $\mathrm{N}$ fixed. For rotation, the balances refer to two cropping cycles, while intercropping covers one season.

\subsection{Data Analysis}

Data were analyzed using SAS version 9.1 statistical software for Windows. Tillage, crop residue and cropping system were fixed effects, while replicates were treated as random effects in the procedure "Mixed". The statistical analysis for this split-split plot study was done according to the model of [16] for such a design. Pair-wise comparison of treatment means was done using the Tukey-Kramer method. Before analysis, nodule counts were log transformed and then back-transformed after the analysis.

\section{Results}

\subsection{Nodulation}

There were no large differences in nodulation between intercrop and the rotation systems (Table 1). Nodulation was always better in CT than in RT. For instance, nodulation was always lower $(P<0.05)$ under 'RT $-\mathrm{CR}$ ' than in CT treatments (e.g., nodule weight was $38 \%$ to $68 \%$ lower than any of the other treatments). Application of $\mathrm{CR}$ resulted in $>33 \%$ increases in nodule mass in RT, but was variable in $\mathrm{CT}$ (i.e., a positive effect in intercrop but no change in rotation).

Table 1. Average nodule number and weight $\left(\mathrm{kg} \mathrm{ha}^{-1}\right)$ at podding as observed over four seasons between 2003 and 2005 in Nyabeda, western Kenya.

\begin{tabular}{|c|c|c|}
\hline Treatment & $\begin{array}{c}\text { Nodule weight } \\
\left(\mathrm{mg} \mathrm{plant}^{-1}\right)\end{array}$ & $\begin{array}{c}\text { Number of nodules } \\
\mathbf{m}^{-2} \\
\end{array}$ \\
\hline \multicolumn{3}{|c|}{ Intercrop } \\
\hline Conventional tillage $-\mathrm{CR}$ & $187 \mathrm{~b}$ & $142 \mathrm{a}$ \\
\hline Conventional tillage $+\mathrm{CR}$ & $257 \mathrm{a}$ & $198 \mathrm{a}$ \\
\hline Reduced tillage $-\mathrm{CR}$ & $93 \mathrm{c}$ & $61 \mathrm{~b}$ \\
\hline Reduced tillage $+\mathrm{CR}$ & $150 \mathrm{cb}$ & $193 \mathrm{a}$ \\
\hline$S E D$ & 33.8 & 27 \\
\hline \multicolumn{3}{|c|}{ Rotation } \\
\hline Conventional tillage $-\mathrm{CR}$ & $177 \mathrm{a}$ & $96 \mathrm{a}$ \\
\hline Conventional tillage $+\mathrm{CR}$ & $189 \mathrm{a}$ & $122 \mathrm{a}$ \\
\hline Reduced tillage $-\mathrm{CR}$ & $92 \mathrm{~b}$ & $45 \mathrm{~b}$ \\
\hline Reduced tillage $+\mathrm{CR}$ & $142 \mathrm{ab}$ & $86 \mathrm{a}$ \\
\hline$S E D$ & 26.8 & 19.7 \\
\hline
\end{tabular}

$\mathrm{CR}=$ crop residue; $\mathrm{SED}=$ standard error of differences of means, values in the same column and cropping system followed by the same letter are not significantly different at $P=0.05$. All treatments were applied with $60 \mathrm{~kg} \mathrm{P} \mathrm{ha}^{-1}$ but no chemical $\mathrm{N}$ fertilizer. 
The effects of fertilizer $\mathrm{N}$ and $\mathrm{P}$ on nodulation in a rotation system were analyzed (Figure 1). Application of $\mathrm{P}$ alone $(-\mathrm{N}+\mathrm{P})$ resulted in higher nodule weight $(P<0.05)$; it was 3 to 16 times higher than the control $(-\mathrm{N}-\mathrm{P})$, and 1.5 to 4 times higher than when $\mathrm{N}$ and $\mathrm{P}$ were given together $(+\mathrm{N}+\mathrm{P})$. Lower nodulation with application of inorganic $\mathrm{N}$ fertilizer was expected due to lower plant demand for fixed-N. Since application of $\mathrm{P}$ without $\mathrm{N}$ was the most promising strategy, soybean nitrogen fixation was investigated further only under this system, using the ${ }^{15} \mathrm{~N}$ dilution method.

Figure 1. Effect of fertilizer $\mathrm{N}$ and $\mathrm{P}$ on soybean nodule weight in different seasons in Nyabeda, western Kenya, within soybean-maize rotation system. LR = long rainy season (usually March to August); SR = short rainy season (usually September to January), nitrogen and phosphorus were each applied at $60 \mathrm{~kg} \mathrm{~N}^{-1}$ in plots indicated $+\mathrm{N}$ and $+\mathrm{P}$, error bars are least significant differences.

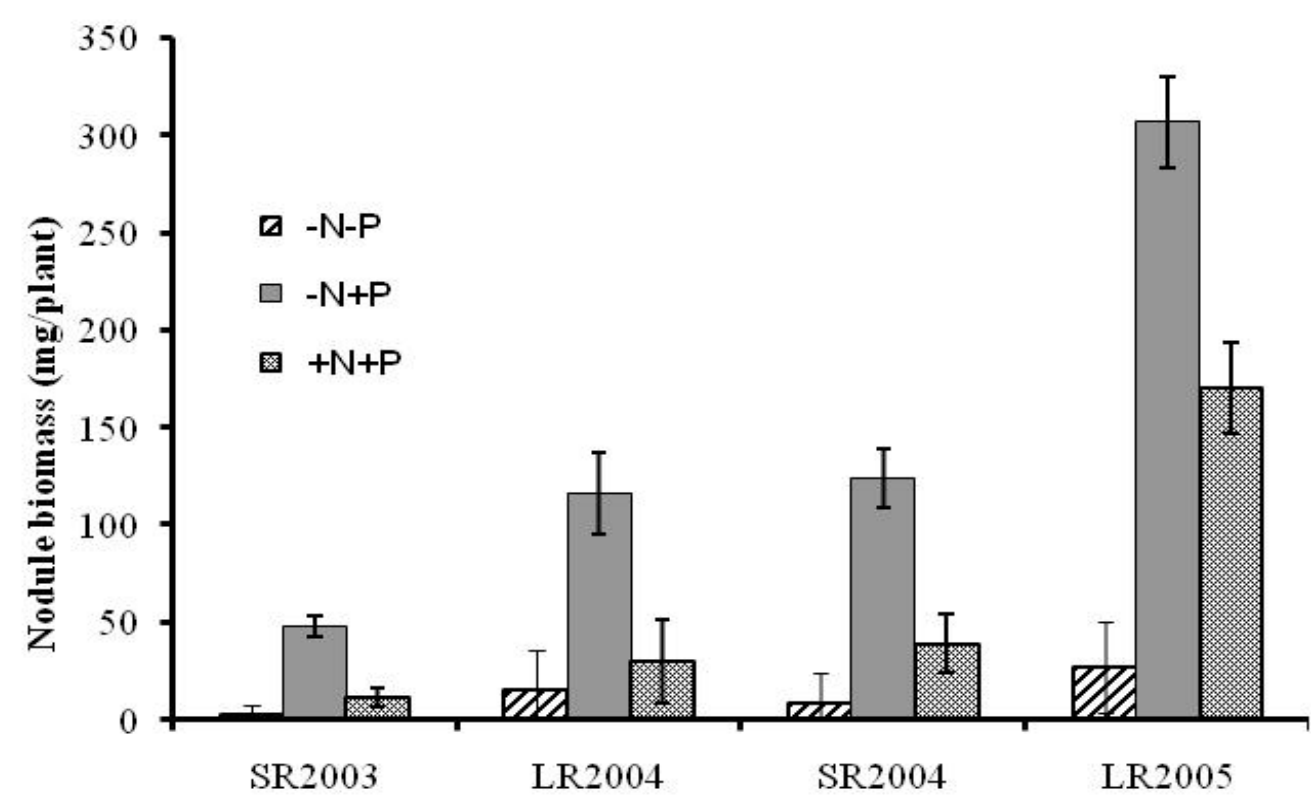

\subsection{Soybean Below- and Above-Ground Biomass}

Tillage and CR had no significant effect on products harvested at physiological maturity, except for litter-fall in the rotation system; here the litter-fall was greater (by 29 to $43 \%$; $P<0.05$ ) in 'RT - CR' than in the other treatments (Table 2). In the intercropping system, soybean grain yield in 'RT - CR' was about $50 \%$ of that with CR application (though not significant). The litter-fall at physiological maturity (Table 2) on average constituted about $64 \%$ of the total litter-fall observed up to harvest, both for intercropping and rotation (Figure 2). The first leaf abscission occurred about 60 days after planting, followed by a 3-week lag phase after which leaf-fall increased rapidly; this can be related to the physiological stage of the soybean crop. 
Table 2. Soybean yield $\left(\mathrm{t} \mathrm{ha}^{-1}\right)$ at physiological maturity as observed in Nyabeda, western Kenya, March-August 2007 cropping season.

\begin{tabular}{lccccc}
\hline Treatment & Grain & Stems + leaves & Husks & Litter-fall & Root \\
\hline \multicolumn{5}{c}{ Intercrop $\left(\mathrm{t} \mathrm{ha}^{-1}\right)$} \\
Conventional tillage $-\mathrm{CR}$ & $0.64 \mathrm{a}$ & $1.19 \mathrm{a}$ & $0.52 \mathrm{a}$ & $0.52 \mathrm{a}$ & $0.24 \mathrm{a}$ \\
Conventional tillage + CR & $0.50 \mathrm{a}$ & $1.19 \mathrm{a}$ & $0.51 \mathrm{a}$ & $0.59 \mathrm{a}$ & $0.24 \mathrm{a}$ \\
Reduced tillage $-\mathrm{CR}$ & $0.35 \mathrm{a}$ & $0.96 \mathrm{a}$ & $0.44 \mathrm{a}$ & $0.43 \mathrm{a}$ & $0.18 \mathrm{a}$ \\
Reduced tillage + CR & $0.71 \mathrm{a}$ & $1.18 \mathrm{a}$ & $0.49 \mathrm{a}$ & $0.45 \mathrm{a}$ & $0.22 \mathrm{a}$ \\
Average & 0.55 & 1.13 & 0.49 & 0.50 & 0.22 \\
SE & 0.171 & 0.270 & 0.065 & 0.053 & 0.035 \\
\hline \multicolumn{5}{c}{ Rotation $\left(\mathrm{t} \mathrm{ha}^{-1}\right)$} \\
Conventional tillage $-\mathrm{CR}$ & $1.09 \mathrm{a}$ & $1.91 \mathrm{a}$ & $0.53 \mathrm{a}$ & $0.53 \mathrm{~b}$ & $0.36 \mathrm{a}$ \\
Conventional tillage $+\mathrm{CR}$ & $1.20 \mathrm{a}$ & $2.15 \mathrm{a}$ & $0.48 \mathrm{a}$ & $0.59 \mathrm{~b}$ & $0.43 \mathrm{a}$ \\
Reduced tillage $-\mathrm{CR}$ & $1.12 \mathrm{a}$ & $2.18 \mathrm{a}$ & $0.50 \mathrm{a}$ & $0.76 \mathrm{a}$ & $0.32 \mathrm{a}$ \\
Reduced tillage $+\mathrm{CR}$ & $1.25 \mathrm{a}$ & $2.03 \mathrm{a}$ & $0.52 \mathrm{a}$ & $0.57 \mathrm{~b}$ & $0.33 \mathrm{a}$ \\
Average & 1.16 & 2.07 & 0.51 & 0.61 & 0.36 \\
SE & 0.171 & 0.213 & 0.049 & 0.080 & 0.039 \\
\hline
\end{tabular}

$\mathrm{SE}=$ standard error; $\mathrm{CR}=$ crop residue.

Figure 2. Soybean litter-fall in soybean-maize intercropping and rotation systems in Nyabeda, western Kenya, March-August 2007 cropping season. Sampling at physiological maturity was at 115 days after planting; $\mathrm{RT}=$ reduced tillage; $\mathrm{CT}=$ conventional tillage. Error bars are standard errors of the mean. All treatments had crop residue applied at $2 \mathrm{t} \mathrm{ha}^{-1}$.

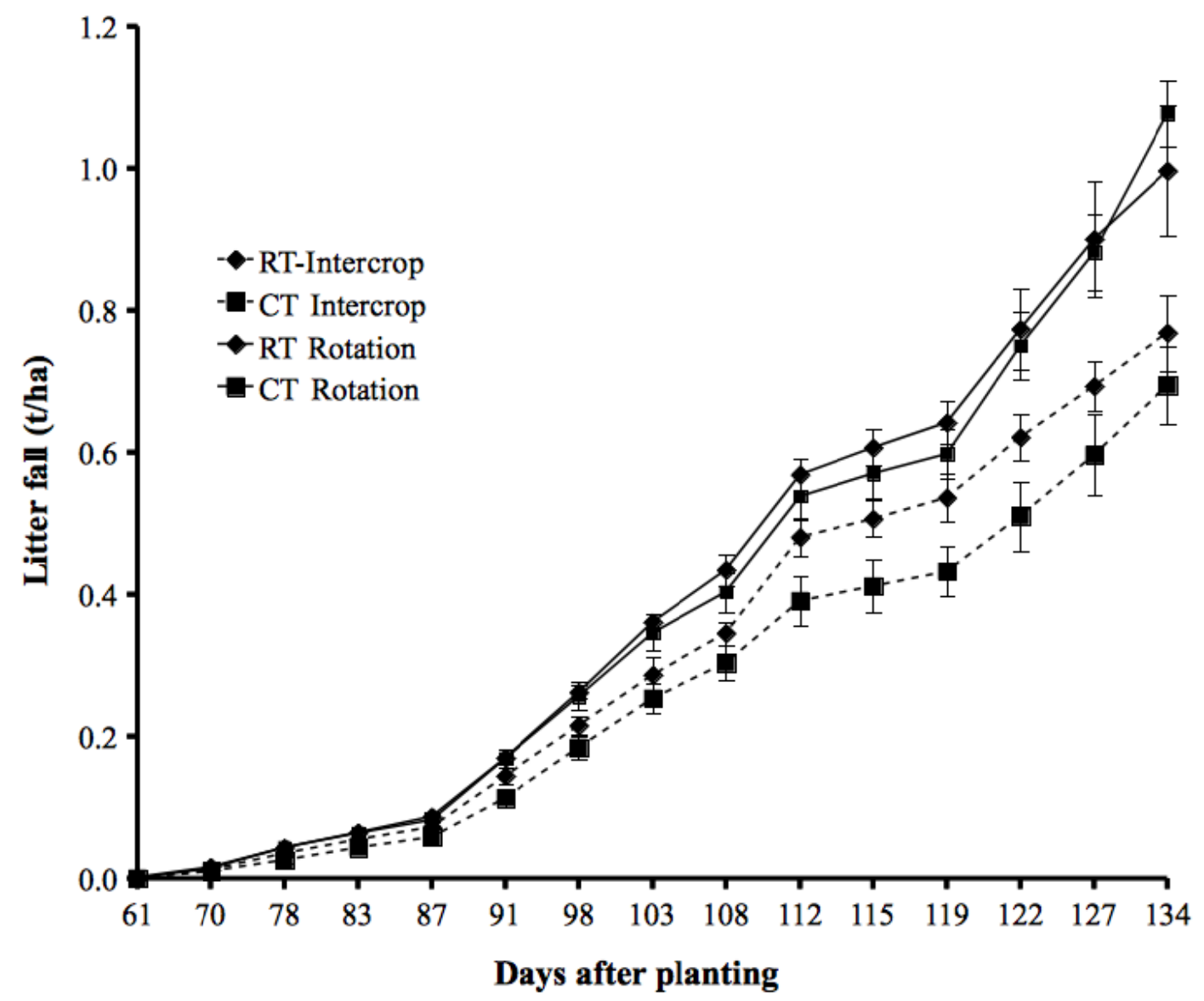




\subsection{Nitrogen Derived from the Atmosphere (NDfA)}

Distribution of atom $\%{ }^{15} \mathrm{~N}$ excess varied significantly between plant parts, with the highest concentration being found in roots, followed by stems and leaves, and similar values in husks and grain (Table 3). Such distribution was expected due to fractionation of ${ }^{15} \mathrm{~N}$ and ${ }^{14} \mathrm{~N}$ isotopes during transfer and reallocation of $\mathrm{N}$-containing compounds to different plant parts in response to demand (see $[17,18]$ ). The relative difference in atom $\%{ }^{15} \mathrm{~N}$ excess, between the fixing and non-fixing (reference) plants, is used for determining the amount of fixed $\mathrm{N}$. The atom $\%{ }^{15} \mathrm{~N}$ excess values in the reference plant were only $2 \%$ higher than in the fixing plant in the roots, but more than double for grain, husks, and stems and leaves. Thus, differences in root atom $\%{ }^{15} \mathrm{~N}$ excess levels between fixing and non-fixing crops were small, suggesting that little of the fixed $\mathrm{N}$ was held in the roots. The roots were thus excluded from further consideration in the assessment of BNF. Total nitrogen concentration was highest in grain and lowest in roots for both fixing and non-fixing plants. Soybean grain $\% \mathrm{~N}$ was greatly affected by cropping system $(5.9 \%$ in intercrop and $6.1 \%$ in rotation; $P<0.01)$.

Table 3. Isotope ${ }^{15} \mathrm{~N}$ excess and total $\mathrm{N}$ concentration in different fixing and non-fixing plant parts in Nyabeda, western Kenya, March-August 2007 cropping season.

\begin{tabular}{lcccc}
\hline \multirow{2}{*}{ Crop part } & \multicolumn{2}{c}{ Fixing plant } & \multicolumn{2}{c}{ Reference plant } \\
\cline { 2 - 5 } & atom $\mathbf{\%}^{\mathbf{1 5}} \mathbf{N}$ excess & $\mathbf{\% ~ N}$ & atom $\mathbf{\%}^{\mathbf{1 5}} \mathbf{N}$ excess & \% N \\
\hline Stems + leaves & $0.0670 \mathrm{~b}$ & $1.33 \mathrm{~b}(1.19-1.48)$ & $0.1463 \mathrm{~b}$ & $0.51 \mathrm{~b}(0.45-0.57)$ \\
Husks & $0.0589 \mathrm{cb}$ & $1.42 \mathrm{~b}(1.28-1.57)$ & $0.1237 \mathrm{c}$ & $0.51 \mathrm{~b}(0.45-0.57)$ \\
Grain & $0.0547 \mathrm{c}$ & $6.01 \mathrm{a}(5.87-6.15)$ & $0.1156 \mathrm{c}$ & $1.26 \mathrm{a}(1.20-1.32)$ \\
Roots & $0.1700 \mathrm{a}$ & $1.04 \mathrm{c}(0.89-1.18)$ & $0.1738 \mathrm{a}$ & $0.40 \mathrm{c}(0.34-0.46)$ \\
Abscised leaves & - & $1.60(1.39-1.94)$ & - & - \\
$S E$ & 0.00612 & 0.072 & 0.00536 & 0.031 \\
\hline
\end{tabular}

Numbers in bracket are lower and upper confidence limits, respectively; abscised leaves were not included in analysis of variance for total $\mathrm{N}$, as only few bulked representative samples had been determined; $\mathrm{SE}=$ standard error; values in the same column followed by the same letter are not significantly different at $P<0.05$.

In general, the proportion of soybean $\mathrm{N}$ derived from biological fixation ranged from 42 to $57 \%$ in the intercropping and 47 to $65 \%$ in the rotation system (Table 4). Regardless of the cropping system, practicing RT increased $(P<0.05)$ total (and also grain) \%NDfA (a difference of 9\% NDfA) relative to that in $\mathrm{CT}$, and in contrast to nodulation observed at least 2 years earlier. Increased \%NDfA in RT resulted in decreased nitrogen derived from the soil (NDfS) of $42 \%$ in contrast to $51 \%$ in $\mathrm{CT}(P<0.05$; data not shown).

There was no significant effect of $\mathrm{CR}$ on \%NDfA. However, in the rotation system, CR application resulted in a large increase $(P<0.05)$, from 47 to $65 \%$ total NDfA in RT, and a slight (insignificant) decrease in CT. The slightly decreased \%NDfA in both cropping systems (a difference of $4 \%$ and $10 \%$ NDfA in intercropping and rotation systems, respectively) following application of CR in CT is attributable to possibly increased available $\mathrm{N}$ following mineralization of the incorporated residue. 
Table 4. Nitrogen derived from the air (\%NDfA) from soybean intercropped and rotated with maize in Nyabeda, western Kenya, March-August 2007 cropping season.

\begin{tabular}{|c|c|c|c|c|}
\hline Treatment & Grain & Stems + leaves & Husks & Total $^{\#}$ \\
\hline \multicolumn{5}{|c|}{ Intercrop (\%NDfA) } \\
\hline Conventional tillage $-\mathrm{CR}$ & $44.6 \mathrm{a}$ & $54.6 \mathrm{a}$ & $36.3 \mathrm{a}$ & $46.3 \mathrm{a}$ \\
\hline Conventional tillage $+\mathrm{CR}$ & $42.6 \mathrm{a}$ & $43.1 \mathrm{a}$ & $40.9 \mathrm{a}$ & $42.0 \mathrm{a}$ \\
\hline Reduced tillage $-\mathrm{CR}$ & $60.4 \mathrm{a}$ & $58.0 \mathrm{a}$ & $53.8 \mathrm{a}$ & $56.5 \mathrm{a}$ \\
\hline Reduced tillage $+\mathrm{CR}$ & $57.1 \mathrm{a}$ & $57.2 \mathrm{a}$ & $47.9 \mathrm{a}$ & $54.4 \mathrm{a}$ \\
\hline Average & 51.2 & 53.2 & 44.7 & 49.8 \\
\hline$S E$ & 6.5 & 8.28 & 5.32 & 5.72 \\
\hline \multicolumn{5}{|c|}{ Rotation (\%NDfA) } \\
\hline Conventional tillage $-\mathrm{CR}$ & $55.6 \mathrm{ab}$ & $59.7 \mathrm{a}$ & $58.8 \mathrm{ab}$ & $57.6 \mathrm{ab}$ \\
\hline Conventional tillage $+\mathrm{CR}$ & $41.4 \mathrm{~b}$ & $52.3 \mathrm{a}$ & $43.6 \mathrm{c}$ & $47.0 \mathrm{~b}$ \\
\hline Reduced tillage $-\mathrm{CR}$ & $48.8 \mathrm{~b}$ & $45.6 \mathrm{a}$ & $54.3 \mathrm{bc}$ & $46.7 \mathrm{~b}$ \\
\hline Reduced tillage $+\mathrm{CR}$ & $67.2 \mathrm{a}$ & $65.0 \mathrm{a}$ & $67.6 \mathrm{a}$ & $64.9 \mathrm{a}$ \\
\hline average & 53.2 & 55.6 & 56.1 & 54.1 \\
\hline$S E$ & 4.9 & 6.56 & 7.25 & 4.61 \\
\hline$S E^{\S}$ & 5.77 & 7.47 & 6.36 & 3.96 \\
\hline
\end{tabular}

\subsection{Nitrogen Fixed}

The amount of fixed $\mathrm{N}$ in soybean aboveground plant parts was $26-48 \mathrm{~kg} \mathrm{~N} \mathrm{ha}^{-1}$ in the intercropping and 53-82 kg N ha ${ }^{-1}$ in the rotation system (Table 5). The lower $\mathrm{N}$ fixation in intercropping is attributed to the observed lower plant harvest biomass due to competition effects of the superimposed maize crop. Under both rotation and intercropping, practicing 'RT $+\mathrm{CR}$ ' led to the highest grain and biomass $\mathrm{N}$ as well as total fixed $\mathrm{N}$ when compared to $\mathrm{CT}$ and ' $\mathrm{RT}-\mathrm{CR}$ ' treatments. Total fixed $\mathrm{N}$ in ' $\mathrm{RT}+\mathrm{CR}$ ' was, for instance, higher than in the other treatments by at least $55 \%$ in the soybean-maize intercropping and $34 \%$ in the rotation system. The lowest total amount of fixed $\mathrm{N}$ was observed in the CT system, for both intercropping and rotation systems.

Unlike with \%NDfA, application of CR did not significantly increase the total amount of fixed $\mathrm{N}$ under RT although this was appreciably raised by $34 \%$ and $64 \%$ in rotation and intercropping systems, respectively, and slightly suppressed under CT (by $9 \%$ and $14 \%$ in rotation and intercropping, respectively).

By the time of physiological maturity, the amount of nitrogen biologically fixed in shed leaves ranged from 3.7 to $5.8 \mathrm{~kg} \mathrm{~N}^{-1}$, representing about $54 \%$ of the total $\mathrm{N}$ contained in leaf-fall by the time of physiological maturity. 
Table 5. Nitrogen fixed $\left(\mathrm{kg} \mathrm{N} \mathrm{ha}^{-1}\right)$ in soybean under intercrop and rotation with maize in Nyabeda, western Kenya, March-August 2007 cropping season.

\begin{tabular}{|c|c|c|c|c|c|}
\hline Treatment & Grain & Stems + leaves & Husks & Litter-fall & Total \\
\hline \multicolumn{6}{|c|}{ Intercrop $\left(\mathrm{kg} \mathrm{N} \mathrm{ha}^{-1}\right)$} \\
\hline Conventional tillage $-\mathrm{CR}$ & $14.9 \mathrm{a}$ & $7.4 \mathrm{a}$ & $2.8 \mathrm{a}$ & $5.6 \mathrm{a}$ & $30.7 \mathrm{a}$ \\
\hline Conventional tillage $+\mathrm{CR}$ & $12.3 \mathrm{a}$ & $6.8 \mathrm{a}$ & $3.5 \mathrm{a}$ & $3.8 \mathrm{a}$ & $26.3 \mathrm{a}$ \\
\hline Reduced tillage $-\mathrm{CR}$ & $12.8 \mathrm{a}$ & $7.9 \mathrm{a}$ & $3.4 \mathrm{a}$ & $4.7 \mathrm{a}$ & $28.9 \mathrm{a}$ \\
\hline Reduced tillage $+\mathrm{CR}$ & $28.2 \mathrm{a}$ & $12.2 \mathrm{a}$ & $3.5 \mathrm{a}$ & $3.7 \mathrm{a}$ & $47.5 \mathrm{a}$ \\
\hline Average & 17.0 & 8.6 & 3.3 & 4.5 & 33.4 \\
\hline$S E$ & 7.97 & 3.86 & 0.80 & 1.00 & 11.80 \\
\hline \multicolumn{6}{|c|}{ Rotation $\left(\mathrm{kg} \mathrm{N} \mathrm{ha}^{-1}\right)$} \\
\hline Conventional tillage $-\mathrm{CR}$ & $35.9 \mathrm{a}$ & $14.3 \mathrm{a}$ & $3.7 \mathrm{ab}$ & $4.9 \mathrm{a}$ & $58.7 \mathrm{a}$ \\
\hline Conventional tillage $+\mathrm{CR}$ & $30.3 \mathrm{a}$ & $15.7 \mathrm{a}$ & $2.5 \mathrm{~b}$ & $4.6 \mathrm{a}$ & $53.2 \mathrm{a}$ \\
\hline Reduced tillage $-\mathrm{CR}$ & $37.7 \mathrm{a}$ & $14.8 \mathrm{a}$ & $4.1 \mathrm{ab}$ & $5.1 \mathrm{a}$ & $61.7 \mathrm{a}$ \\
\hline Reduced tillage $+\mathrm{CR}$ & $52.0 \mathrm{a}$ & $19.5 \mathrm{a}$ & $5.1 \mathrm{a}$ & $5.8 \mathrm{a}$ & $82.4 \mathrm{a}$ \\
\hline Average & 39.0 & 16.1 & 3.9 & 5.1 & 64.0 \\
\hline$S E$ & 9.18 & 2.62 & 0.72 & 0.63 & 10.51 \\
\hline
\end{tabular}

$\mathrm{CR}=$ crop residue; $\mathrm{SE}=$ standard error; values in the same column and cropping system followed by the same letter are not significantly different at $P<0.05$.

\subsection{Nitrogen Balance}

Overall, the net nitrogen balances varied from -19 to $+8 \mathrm{~kg} \mathrm{~N} \mathrm{ha}^{-1}$ when only harvest soybean grain was removed, and from -51 to $-9 \mathrm{~kg} \mathrm{~N}$ ha $^{-1}$ when also maize grain was removed (Table 6). With only soybean grain removed, positive $\mathrm{N}$ balances were observed in the two RT treatments ('RT + CR' and ' $R T-C R$ ') in intercropping and in ' $R T$ + CR' treatment in the rotation system. Although the balances were all in the negative range when both soybean and maize grain were removed, the balances in the rotation system, for example, were better in 'RT $+\mathrm{CR}$ ' than in the other treatments $(P<0.05)$. Also, balances with soybean and maize grain removed were better in RT ( -10 to $\left.-33 \mathrm{~kg} \mathrm{~N} \mathrm{ha}^{-1}\right)$ than in CT ( -42 to $-66 \mathrm{~kg} \mathrm{~N} \mathrm{ha}^{-1}$ ), assuming two seasons for the intercrop. The differences in the balances are a result of both the \%NDfA and the amount of harvested products.

Table 6. Nitrogen balance in soybean-maize intercropping and rotation systems in Nyabeda, western Kenya, March-August 2007 cropping season.

\begin{tabular}{lccccc}
\hline & Total $\mathbf{N}$ & \multicolumn{2}{c}{ Total N harvested in grain } & \multicolumn{2}{c}{ Net balances } \\
\cline { 3 - 6 } Treatment & fixed & Soybean & Maize & $\begin{array}{c}\text { Soybean grain } \\
\text { removed }\end{array}$ & $\begin{array}{c}\text { Soybean + maize } \\
\text { grain removed }\end{array}$ \\
\hline & & \multicolumn{2}{c}{ Intercrop $\left(\mathrm{kg} \mathrm{N} \mathrm{ha}^{-1}\right)$} \\
\hline Conventional tillage $-\mathrm{CR}$ & $30.7 \mathrm{a}$ & $38.3 \mathrm{a}$ & $23.1 \mathrm{a}$ & $-10.0 \mathrm{~b}$ & $-33.1 \mathrm{~b}$ \\
Conventional tillage +CR & $26.3 \mathrm{a}$ & $28.3 \mathrm{a}$ & $18.0 \mathrm{a}$ & $-3.3 \mathrm{ab}$ & $-21.3 \mathrm{ab}$ \\
Reduced tillage - CR & $28.9 \mathrm{a}$ & $21.2 \mathrm{a}$ & $17.4 \mathrm{a}$ & $7.9 \mathrm{a}$ & $-9.4 \mathrm{a}$ \\
Reduced tillage + CR & $47.5 \mathrm{a}$ & $43.5 \mathrm{a}$ & $18.2 \mathrm{a}$ & $3.4 \mathrm{ab}$ & $-14.9 \mathrm{ab}$ \\
Average & 33.4 & 32.8 & 19.2 & -0.5 & -19.7 \\
SE & 11.80 & 10.87 & 4.02 & 4.3 & 6.1 \\
\hline
\end{tabular}


Table 6. Cont.

\begin{tabular}{lccccc}
\hline & Total $\mathbf{N}$ & \multicolumn{2}{c}{ Total N harvested in grain } & \multicolumn{2}{c}{ Net balances } \\
\cline { 3 - 6 } Treatment & fixed & Soybean & Maize & $\begin{array}{c}\text { Soybean grain } \\
\text { removed }\end{array}$ & $\begin{array}{c}\text { Soybean + maize } \\
\text { grain removed }\end{array}$ \\
\hline & & \multicolumn{2}{c}{ Rotation $\left(\mathrm{kg} \mathrm{N} \mathrm{ha}^{-1}\right)$} \\
\hline Conventional tillage $-\mathrm{CR}$ & $58.7 \mathrm{a}$ & $63.8 \mathrm{a}$ & $47.1 \mathrm{a}$ & $-4.3 \mathrm{ab}$ & $-51.4 \mathrm{~b}$ \\
Conventional tillage $+\mathrm{CR}$ & $53.2 \mathrm{a}$ & $72.7 \mathrm{a}$ & $25.3 \mathrm{~b}$ & $-18.6 \mathrm{c}$ & $-43.9 \mathrm{~b}$ \\
Reduced tillage -CR & $61.7 \mathrm{a}$ & $72.5 \mathrm{a}$ & $21.4 \mathrm{~b}$ & $-11.3 \mathrm{bc}$ & $-32.7 \mathrm{~b}$ \\
Reduced tillage +CR & $82.4 \mathrm{a}$ & $76.3 \mathrm{a}$ & $15.1 \mathrm{~b}$ & $4.7 \mathrm{a}$ & $-10.4 \mathrm{a}$ \\
Average & 64.0 & 71.3 & 27.2 & -7.4 & -34.6 \\
SE & 10.51 & 10.75 & 4.92 & 3.3 & 6.6 \\
\hline
\end{tabular}

$\mathrm{CR}=$ crop residue; $\mathrm{SE}=$ standard error; values in the same column and cropping system followed by the same letter are not significantly different at $P<0.05$.

\section{Discussion}

\subsection{Factors Affecting Nitrogen Fixation}

The \%NDfA values observed in this study are in agreement with previous results of $54 \%$ NDfA for $P$ fertilized soybean in the high rainfall zone of western Kenya [19]. The greater \%NDfA observed in RT when CR was also applied, and the resultant higher amount of fixed N compared to disturbed soils (such as in CT) has been attributed to the greater colonization by arbuscular mycorrhizae that increases P supply to the nodules [4]. We also observed higher fungal presence under RT compared to conventionally tilled plots (data not shown), similar to other studies [20,21]. Legumes are generally dependent on mycorrhizae for efficient uptake of $\mathrm{P}$, and diversity of mycorrhizae is related positively to efficient use of soil P [22]. In the same experimental field used for this study, [23] observed low available $\mathrm{P}$ values of $10 \mathrm{mg} \mathrm{P} \mathrm{kg}{ }^{-1}$ soil in ' $\mathrm{RT}-\mathrm{CR}$ ', compared to over $22 \mathrm{mg} \mathrm{P} \mathrm{kg}{ }^{-1}$ soil in the 'RT + CR' and the two CT treatments and attributed to increased P losses in surface runoff due to crusting in absence of tillage and crop residue application (the critical $\mathrm{P}$ value for soybean growth and nodulation has not been determined but is shown to be $13 \mathrm{ppm}$ elsewhere [24]). Besides mycorrhizae, it was previously shown that also Bradyrhizobia diversity is higher under RT, and N fixation rates of the isolates obtained from RT were observed to be higher than those from CT [25]. This could also apply to our RT treatments, and both diversity of rhizobia and fixation efficiency were likely greater with than without surface $\mathrm{CR}$, leading to the greater nitrogen fixation in 'RT $+\mathrm{CR}$ ' relative to other treatments as observed. However, during the first seasons, microbial communities were probably not yet well established, and available soil $\mathrm{P}$ differences between the tillage systems were likely more pronounced (crusting was a greater problem) than during season 9 when the ${ }^{15} \mathrm{~N}$ dilution method was employed. This explains the inconsistency between nodulation (higher in CT) and \%NDfA (higher in RT) during the two periods.

In addition to microbial contributions and soil $\mathrm{P}$, reduced nodulation (and darker-green soybean leaves and visually observed tendency to delay maturation) following chemical fertilizer $\mathrm{N}$ application is due to the suppressive effect of the increased available N. Similar findings have also been reported by other researchers [26,27]. The reduced \%NDfA and fixed N in CT as opposed to RT (e.g., in the 
rotation system) can also be attributed to the suppressive effect of a possibly larger amount of available soil N than in RT systems [10,27,28]. Such greater N in CT than in RT can be the result of the usually higher mineralization of nutrients in organic matter following perturbations by tillage [27]. With CT, the stronger depressive effect of incorporated CR on \%NDfA in rotation as opposed to intercropping may be due to the fact that the mineralized $\mathrm{N}$ was fully at the disposal of the soybean alone, whereas this was shared among the jointly planted crops (soybean and maize) in the intercropping system. A similar effect was not observed with nodulation (nodulation was higher in CT than in RT), which was perhaps mainly influenced by differences in soil $\mathrm{P}$ as already discussed. Unlike with incorporated residue, the positive effect with surface residue (RT) on $\mathrm{N}$ fixation might be attributed to the modified micro-climate under residues, reduced plant water stress during the dry periods due to soil moisture conservation (leading to increased plant demand for fixed N [7]), and reduced soil temperature [29]; these factors were likely minimized or absent when surface CR was not applied or when much of it was incorporated into the soil (e.g., in CT).

Lower soybean \%NDfA in the intercropping system is in agreement with previous reports such as the 42 and 23\% NDfA found under monocrop and intercrop, respectively, as reported by [27]. Fujita et al. (1992) identified shading and light availability as important factors reducing BNF in mixed legume-cereal systems [30]. Perhaps the lack of CR effect on \%NDfA observed under the intercropping system was due to soybean-maize interaction effects such as shading and nutrient and water competition. Data for multiple seasons provide further insights. For instance, rainfall would be a plausible explanation for the seasonal differences in nodulation; the amount of seasonal rainfall was low in the short rains (SR) 2003 season, and in long rains (LR) 2004 and SR 2004 seasons, rainfall amount was poorly distributed compared to LR 2005 season.

\subsection{Nitrogen Fixed and $N$ Balances}

In general, fixed $\mathrm{N}$ in the intercropping system was just about $50 \%$ of the fixed $\mathrm{N}$ in the rotation system. However, assuming two cropping seasons in a year, and assuming that a similar amount of $\mathrm{N}$ is fixed during the second intercrop season during the cereal phase of the rotation system, similar quantities of $\mathrm{N}$ could be fixed annually in both intercropping and rotation. The amount of fixed $\mathrm{N}$ in the rotation system was within the range of 51 to $78 \mathrm{~kg} \mathrm{~N}^{-1}$ observed by [31] in various farms in Nigeria. Other researchers have reported different amounts of fixed N. For instance, Peoples et al. (1995) reported $\mathrm{N}$ fixed by soybean of between 44 to $250 \mathrm{~kg} \mathrm{~N} \mathrm{ha}^{-1}$ per season [32]. Our results imply that in both cropping systems, practicing RT while adding CR in quantities accessible to farmers results in elevated (not significant) amounts of biologically fixed $\mathrm{N}$, which is in line with our hypothesis. The reported quantity of fixed $\mathrm{N}$ in the current study could be an underestimation, since an appreciable amount of fixed $\mathrm{N}$ in soybean, reaching up to $30 \%$ of the $\mathrm{N}$ being fixed at pod-filling [33], is said to be released by the root system into the soil nutrient medium [30].

Nitrogen balances of crop fields that include grain legumes vary widely and are affected by site conditions, grain harvest and $\mathrm{N}$ input [27]. Although in the present study $42 \%$ to $65 \%$ of soybean $\mathrm{N}$ was obtained from BNF, this could not turn then balance into a positive one. Similar soybean $\mathrm{N}$ balances have been reported for Argentina [34] and Switzerland [35]. In fact, in their review of BNF studies that had been conducted between 1966 and 2006, [8] observed that the amount of fixed $\mathrm{N}$ in 
soybean (a grain legume as opposed to non-grain legumes or legumes where the grain is usually not harvested) was, in most cases, insufficient to replace all the $\mathrm{N}$ removed in harvested seed. Some positive $\mathrm{N}$ balances after soybean seed harvest were found in our study mainly in the 'RT + CR' treatments, suggesting that adoption of 'RT $+\mathrm{CR}$ ' could save some cash the farmers would otherwise spend on fertilizers. For instance, for two cropping seasons (annually), an additional 10 to $30 \mathrm{~kg} \mathrm{~N}^{-1}$ is required in RT, which is about half or less of the 40 to $60 \mathrm{~kg} \mathrm{~N}^{-1}$ required in CT to compensate for harvested $\mathrm{N}$. The farmers would also achieve a higher soybean grain yield over other treatments of 50 to $160 \mathrm{~kg} \mathrm{ha}^{-1}$ in rotation and 70 to $360 \mathrm{~kg} \mathrm{ha}^{-1}$ in intercropping by using 'RT + CR'. Although soybean can have a positive $\mathrm{N}$ balance (after soybean grain removal), the fixed $\mathrm{N}$ cannot also compensate for the entire $\mathrm{N}$ harvested in the maize grain. Chikowo et al. (2004) studied a similar case in a sandy soil in southern Africa and concluded that a combination of legume rotations and mineral fertilizer application would be the best option [36].

In terms of residue management, small-scale farmers usually transfer above-ground biomass to the homestead, where threshing is done with ease, and the residues are heaped in a corner where they rot. Since, residues contain total $\mathrm{N}$ of up to $30 \mathrm{~kg} \mathrm{~N} \mathrm{ha}^{-1}$ as for the rotation system, we recommend that soybean residues after removal of grains be returned to the field plots after harvest, especially in the soybean-maize rotation system, to reduce soil $\mathrm{N}$ mining. Overall, gross margin analysis showed legume-based systems to dominate all maize-maize rotation system in the same trial [23].

\subsection{Litter-Fall- and Root-N Contribution}

Nitrogen contained in litter-fall occurring from planting to physiological maturity in this study was 8.2 to $11.8 \mathrm{~kg} \mathrm{~N} \mathrm{ha}^{-1}$, but as much as $40 \mathrm{~kg} \mathrm{~N} \mathrm{ha}^{-1}$ can be observed in legume systems [10]. Our accounting took into consideration the $65 \%$ of litter-fall that had occurred before physiological maturity, constituting a fixed $\mathrm{N}$ of 4 to $6 \mathrm{~kg} \mathrm{~N} \mathrm{ha}^{-1}$, representing 54\% NDfA. Nitrogen contained in such litter-fall is not usually taken into consideration in estimation of $\mathrm{N}$-fixation nutrient balances, perhaps because of the small amount of the fixed $\mathrm{N}$, and some of it can be lost within the season. Combination of nutrient and water stress likely induced early leaf abscission resulting to the greater litter-fall observed in ' $\mathrm{RT}-\mathrm{CR}$ ' relative to other rotation treatments at physiological maturity. However, the greater litter-fall did not yet translate to greater soybean grain yield suggesting the need to investigate effect of abscissed litter on soil moisture in future studies.

In both cropping systems, the recovered roots accounted for about $8 \%$ of the total plant biomass, consistent with the observation by [37] that underground grain legume plant parts constitute $<10 \%$ of total standing biomass. The roots may, however, not contribute substantially to fixed $\mathrm{N}$, as they seem to be enriched in ${ }^{15} \mathrm{~N}$ due to isotope ${ }^{15} \mathrm{~N} /{ }^{14} \mathrm{~N}$ fractionation. The fractionation is related to form and concentration of $\mathrm{N}$ in the soil, nitrate reduction in roots, ammonia assimilation, and plant-fungal associations ([17,38]. Wanek and Arndt (2002) [39] reported $\delta^{15} \mathrm{~N}$ enrichment of soybean roots at high \%NDfA, but such enrichment was reversed to the shoots when soil nitrate was high, induced by the switch from nodule activity to mineral $\mathrm{N}$ acquisition. This may explain why roots, although not usually reported in many $\mathrm{N}$ fixation studies [27], are generally found to have more ${ }^{15} \mathrm{~N}$ or $\delta^{15} \mathrm{~N}$ than shoots $[18,40]$. 
In summary, 'RT $+\mathrm{CR}$ ' resulted in the highest \%NDfA and total $\mathrm{N}$ fixed and better N-balances than 'RT - CR' and CT treatments. Thus, in agreement to our hypothesis, practicing RT combined with CR application leads to greater utilization of BNF compared to the other treatments.

\section{Conclusions}

Small-scale farmers in western Kenya can take greater advantage of biological $\mathrm{N}$ fixation by: (i) practicing reduced tillage combined with surface application of crop residue, as this increases biologically fixed $\mathrm{N}$ by at least $34 \%$ over other treatments tested; (ii) applying chemical fertilizer phosphorus; and (iii) returning soybean residues to the farm after grain removal, as such residues were found to contain total $\mathrm{N}$ up to as much as $30 \mathrm{~kg} \mathrm{~N} \mathrm{ha}^{-1}$. By practicing 'reduced tillage plus crop residue', farmers can achieve extra soybean grain yields of 50 to $160 \mathrm{~kg} \mathrm{ha}^{-1}$ in rotation and 70 to $360 \mathrm{~kg} \mathrm{ha}^{-1}$ in intercropping, and better $\mathrm{N}$ balances can be realized than when practicing CT. Soybean roots become enriched with ${ }^{15} \mathrm{~N}$ due to isotope ${ }^{15} \mathrm{~N} /{ }^{14} \mathrm{~N}$ fractionation and do not contribute substantially to total plant fixed N.

\section{Acknowledgements}

This study was financially supported by both the Germany Federal Ministry for Economic Cooperation and Development (BMZ) through the Deutscher Akademischer Austauschdienst (DAAD) and the African Network for Soil Biology and Fertility (AfNet) of the Tropical Soil Biology and Fertility (TSBF) research area of CIAT. The authors acknowledge the assistance of Livingstone Chibore in sample preparation and of Deborah Rupprecht in laboratory analysis.

\section{References}

1. Maatman, A.; Wopereis, M.C.S.; Debrah, K.S.; Groot, J.J.R. From thousands to millions: Accelerating agricultural intensification and economic growth in Sub-Saharan Africa. In Advances in Integrated Soil Fertility Management in Sub-Saharan Africa: Challenges and Opportunities; Bationo, A., Waswa, B., Kihara, J., Kimetu, J., Eds.; Springer: Dordrecht, The Netherlands, 2008; p. 1091.

2. Stoorvogel, J.J.; Smaling, E.M.A.; Janssen, B.H. Calculating soil nutrient balances in Africa at different scales. Nutr. Cycl. Agroecosyst. 1993, 35, 227-235.

3. Mabood, F.; Zhou, X.; Smith, D. Bradyrhizobium japonicum preincubated with Methyl Jasmonate increases soybean nodulation and nitrogen fixation. Agron. J. 2006, 98, 289-294.

4. Goss, M.J.; de Varennes, A. Soil disturbance reduces the efficacy of myccorrhizal associations for early soybean growth and $\mathrm{N}_{2}$ fixation. Soil Biol. Biochem. 2002, 34, 1167-1173.

5. Giller, K.E.; Cadisch, G. Future benefits from biological nitrogen fixation: An ecological approach to agriculture. Plant Soil 1995, 174, 255-277.

6. Rebafka, F.P.; Mndunguru, B.J.; Marschner, H. Crop residue application increases nitrogen fixation and dry matter production in groundnut (Arachis hypogaea L.) grown on an acid sandy soil in Niger, West Africa. Plant Soil 1993, 150, 213-222. 
7. Streeter, J.G. Effects of drought on nitrogen fixation in soybean root nodules. Plant Cell Environ. 2003, 26, 1199-1204.

8. Salvagiotti, F.; Cassman, K.G.; Specht, J.E.; Walters, D.T.; Weiss, A.; Dobermann, A. Nitrogen uptake, fixation and response to fertilizer $\mathrm{N}$ in soybeans: A review. Field Crops Res. 2008, 108, 1-13.

9. Sinclair, T.R.; Purcell, L.C.; King, C.A.; Sneller, C.H.; Chen, P.; Vadez, V. Drought tolerance and yield increase of soybean resulting from improved symbiotic $\mathrm{N}_{2}$ fixation. Field Crops Res. 2007, 101, 68-71.

10. Peoples, M.B.; Craswell, E.T. Biological nitrogen fixation: Investments, expectations and actual contributions to agriculture. Plant Soil 1992, 141, 13-39.

11. Unkovich, M.; Herridge, D.; Peoples, M.; Cadisch, G.; Boddey, B.; Giller, K.; Alves, B.; Chalk, P. Measuring Plant-Associated Nitrogen Fixation in Agricultural Systems; ACIAR Monogragh Series No. 136; Australian Centre for International Agricultural Research: Canberra, Australia 2008; pp. 1-258.

12. Witty, J.F. Estimating $\mathrm{N}_{2}$-fixation in the field using ${ }^{15} \mathrm{~N}$-labelled fertilizer: Some problems and solutions. Soil Biol. Biochem. 1983, 15, 631-639.

13. Okereke, G.U.; Dauda, G.; Ayama, G. Selection of the most appropriate reference crop for the assessment of nitrogen fixation by soya bean in Anambra state, Nigeria. J. Sci. Food Agric. 2006, 57, 101-109.

14. Laboratory Methods of Soil and Plant Analysis; International Centre for Research in Agroforestry (ICRAF): Nairobi, Kenya, 1995.

15. Use of Isotope and Radiation Methods in Soil and Water Management and Crop Nutrition; Training Course Series No. 14; International Atomic Energy Agency (IAEA): Vienna, Austria, 2001.

16. Federer, W.T.; King, F. Variations on Split Plot and Split Block Experiment Designs; John Wiley \& Sons Ltd.: Hoboken, NJ, USA, 2007; p. 270.

17. Yoneyama, T.; Ito, O.; Engelaar, W.M.H.G. Uptake, metabolism and distribution of nitrogen in crop plants traced by enriched and natural ${ }^{15} \mathrm{~N}$ : Progress over the last 30 years. Phytochem. Rev. 2003, 2, 121-132.

18. Steele, K.W.; Bonish, P.M.; Daniel, R.M.; O’Hara, G.W. Effect of rhizobial strain and host plant on nitrogen isotopic fractionation in legumes. Plant Physiol. 1983, 72, 1001-1004.

19. Ojiem, J.O.; Vanlauwe, B.; de Ridder, N.; Giller, K.E. Niche-based assessment of contributions of legumes to the nitrogen economy of western Kenya smallholder farmers. Plant Soil 2007, 292, 119-135.

20. Beare, M.H.; Pohland, B.R.; Wright, D.H.; Coleman, D.C. Residue placement and fungicide effects on fungal communities in conventional and no-tillage soils. Soil Sci. Soc. Am. J. 1993, 57, 392-399.

21. Degens, B.P.; Sparling, G.P.; Abbott, L.K. Increasing the length of hyphae in a sandy soil increases the amount of water-stable aggregates. Appl. Soil Ecol. 1996, 3, 149-159.

22. Vance, C.P. Symbiotic nitrogen fixation and phosphorus acquisition. Plant nutrition in a world of declining renewable resources. Plant Physiol. 2001, 127, 390-397.

23. Maguta, J.K. Conservation Tillage in Kenya: The Biophysical Processes Affecting Its Effectiveness. Ph.D. Thesis, University of Bonn: Bonn, Germany, 2009. 
24. Waluyo, S.H. Significance of pelleting the seed with phosphate and lime on the cultivation of soybean in acid soils in Sitiung, West Sumatra. J. Tanah Lingk. 2005, 7, 58-65.

25. Ferreira, M.C.; Andradeb, D.S.; Chueirea, L.M.O.; Takemuraa, S.M.; Hungria, M. Tillage method and crop rotation effects on the population sizes and diversity of bradyrhizobia nodulating soybean. Soil Biol. Biochem. 2000, 32, 627-637.

26. Ralston, E.J.; Imsande, J. Nodulation of hydroponically grown soybean plants and inhibition of nodule development by nitrate. Exp. Bot. 1983, 34, 1371-1378.

27. Van Kessel, C.; Hartley, C. Agricultural management of grain legumes: Has it led to an increase in nitrogen fixation? Field Crops Res. 2000, 65, 165-181.

28. Wheatley, D.M.; Macleod, D.A.; Jessop, R.S. Influence of tillage treatments on $\mathrm{N}_{2}$ fixation of soybean. Soil Biol. Biochem. 1995, 27, 571-574.

29. Power, J.F.; Wilhelm, W.; Doran, J.W. Crop residue effects on soil environment and dryland maize and soya bean production. Soil Tillage Res. 1986, 8, 101-111.

30. Fujita, K.; Ofosu-budu, K.G.; Ogata, S. Biological nitrogen fixation in mixed legume-cereal cropping systems. Plant Soil 1992, 141, 155-175.

31. Osunde, A.O.; Bala, A.; Gwam, M.S.; Tsado, P.A.; Sanginga, N.; Okogun, J.A. Residual benefits of Promiscuous soybean to maize (Zea mays L.) grown on farmer's field around Minna in the Southern Guinea savanna zone of Nigeria. Agric. Ecosyst. Environ. 2003, 100, 209-220.

32. Peoples, M.B.; Herridge, D.E.; Ladha, J.K. Biological nitrogen fixation: An efficient source of nitrogen for sustainable agricultural production? Plant Soil 1995, 174, 3-28.

33. Ofosu-budu, K.G.; Fujita, K.; Ogata, S. Excretion of ureide and other nitrogenous compounds by the root system of soybean at different growth stages. Plant Soil 1990, 128, 135-142.

34. Di Ciocco, C.; Coviella, C.; Penón, E.; Díaz-Zorita, M.; López, S. Biological fixation of nitrogen and $\mathrm{N}$ balance in soybean crops in the pampas region. Span. J. Agric. Res. 2008, 6, 114-119.

35. Oberson, A.; Nanzer, S.; Bosshard, C.; Dubois, D.; Mäder, P.; Frossard, E. Symbiotic $\mathrm{N}_{2}$ fixation by soybean in organic and conventional cropping systems estimated by ${ }^{15} \mathrm{~N}$ dilution and ${ }^{15} \mathrm{~N}$ natural abundance. Plant Soil 2007, 290, 69-83.

36. Chikowo, R.; Mapfumo, P.; Nyamugafata, P.; Giller, K.E. Maize productivity and mineral N dynamics following different soil fertility management practices on a depleted sandy soil in Zimbabwe. Agric. Ecosyst. Environ. 2004, 102, 119-131.

37. Danso, S.K.; Hardarson, G.; Zapata, F. Misconceptions and practical problems in the use of ${ }^{15} \mathrm{~N}$ soil enrichment techniques for estimating $\mathrm{N}_{2}$ fixation. Plant Soil 1993, 152, 25-52.

38. Högberg, P. ${ }^{15} \mathrm{~N}$ natural abundance in soil-plant systems. New Phytol. 1997, 137, 179-203.

39. Wanek, W.; Arndt, S.K. Differences in $\delta^{15} \mathrm{~N}$ signatures between nodulated roots and shoots of soybean is indicative of the contribution of symbiotic $\mathrm{N}_{2}$ fixation to plant N. J. Exp. Bot. 2002, 53, 1109-1118.

40. Ruschel, A.P.; Salati, E.; Vose, P.B. Nitrogen enrichment of soil and plant by Rhizobium phaseoli-Phaseolus vulgaris symbiosis. Plant Soil 1979, 51, 425-429.

(C) 2011 by the authors; licensee MDPI, Basel, Switzerland. This article is an open access article distributed under the terms and conditions of the Creative Commons Attribution license (http://creativecommons.org/licenses/by/3.0/). 